\title{
Pengaruh Kompensasi, Kepemimpinan dan Fasilitas Kerja Terhadap Kepuasan Kerja Pegawai
}

\author{
Indra Prawira \\ Program Studi Magister Manajemen, Universitas Muhammadiyah Sumatera Utara Medan, Indonesia \\ Jl. Denai No. 217, Tegal Sari Mandala II, Medan Denai, Kota Medan, Sumatera Utara 20371 \\ Email: indpmadani02@gmail.com
}

\begin{abstract}
Abstrak. Permasalahan di Yayasan Generasi Amanah Madani di Kabupaten Deli Serdang, Sumatera Utara adalah rendahnya kepuasan kerja, yang berkaitan dengan kompensasi, kepemimpinan dan fasilitas kerja. Tujuan dari penelitian ini adalah untuk menganalisa dan mengetahui pengaruh kompensasi, kepemimpinan dan fasilitas kerja terhadap kepuasan kerja pegawai, baik secara parsial maupun secara simultan. Penelitian ini merupakan penelitian asosiatif kausal dengan pendekatan deskriptif kuantitatif. Dengan teknik sampel jenuh, jumlah sampel sama dengan jumlah populasi penelitian yaitu seluruh pegawai di Yayasan Generasi Amanah Madani sebanyak 42 orang. Data yang digunakan adalah data primer yaitu data yang diperoleh dari penelitian di lapangan dan data sekunder yang didapat dari buku, jurnal dan literatur lainnya. Hasil penelitian menunjukkan bahwa kompensasi, kepemimpinan dan fasilitas kerja berpengaruh signifikan terhadap kepuasan kerja, baik secara parsial maupun simultan.
\end{abstract}

Kata Kunci : Kompensasi, Kepemimpinan, Fasilitas Kerja, Kepuasan Kerja

\begin{abstract}
The problem at the Generasi Amanah Madani Foundation in Deli Serdang, North Sumatera is low in job satisfaction, related to compensation, leadership and work facilities. The purpose of this research is to analyse and determine the influence of compensation, leadership and work facilities to employee's job satisfaction, both partially and simultaneously. This research is causal associative research with a quantitative descriptive approach. With the technique of saturated samples, the number of samples is equal to the number of research populations, all employees at the Generasi Amanah Madani Foundation as much as 42 people. The data used is primary data that is derived from research in the field and secondary data obtained from books, journals and other literature. The results show that compensation, leadership and work facilities have significant effect on employee's job satisfaction, both partially and simultaneously
\end{abstract}

Keywords : Compensation, Leadership, Work facilities, Job satisfaction

\section{PENDAHULUAN}

Yayasan Generasi Amanah Madani adalah sebuah yayasan pendidikan yang terletak di Kecamatan Percut Sei Tuan, Kabupaten Deli Serdang, Provinsi Sumatera Utara. Yayasan yang berdiri tahun 2006 ini, menyelenggarakan berbagai layanan pendidikan di antaranya Taman Kanak-kanak (TK), Kelompok Bermain (KB), Sekolah Dasar (SD), Madrasah Diniyah Takmiliyah Awwaliyah (MDTA), dan Pusat Kegiatan Belajar Masyarakat (PKBM).

Operasional kegiatan yayasan dilakukan oleh tenaga pendidik yaitu guru dan tutor, serta tenaga kependidikan yaitu kepala sekolah, bagian administrasi, keuangan, kurikulum, sarana dan prasarana, kesiswaan, hubungan masyarakat, kebersihan, keamanan dan lainnya. Seluruh pegawai bekerjasama sesuai peran dan tugasnya masing-masing dalam pencapaian visi organisasi, yaitu menjadi lembaga pendidikan yang unggul dan terpercaya untuk menciptakan masyarakat yang cerdas, berkepribadian, terampil, berdaya saing, serta selalu mengembangkan dirinya dalam pendidikan sepanjang hayat. 
Untuk pencapaian visi organisasi yang efektif, kepuasan kerja pegawai sangat penting diperhatikan. Wibowo, (2014) mendefinisikan, Kepuasan kerja merupakan tingkat perasaan senang seseorang sebagai penilaian positif terhadap pekerjaannya dan lingkungan tempat pekerjaannya. Menurut (Sudaryo, Aribowo, \& Sofiati, 2018), Indikator kepuasan kerja yaitu kedisiplinan, moral kerja dan jumlah turn over atau pergantian pegawai.

Kenyataan di Yayasan Generasi Amanah Madani, dari hasil wawancara dengan salah satu pegawai pada penelitian awal diindikasikan bahwa kepuasan kerja pegawai kurang baik. Hal ini dapat dilihat dari kekurangdisiplinan seperti ketidakhadiran dan datang terlambat, komunikasi dan hubungan antar pegawai yang kurang baik, banyaknya pegawai yang keluar dan mencari pekerjaan lain.

Hal penting lainnya agar operasional organisasi berjalan optimal berkaitan dengan kompensasi. Menurut (Kasmir, 2016), kompensasi adalah balas jasa yang diberikan kepada pegawai, baik yang bersifat keuangan maupun non keuangan. Menurut (Rivai \& Sagala, 2011), indikator kompensasi adalah: (1) upah dan gaji, (2) loyalitas, (3) keadilan, dan (4) penghargaan.

Dari penelitian awal dengan metode wawancara pada salah satu pegawai Yayasan Generasi Amanah Madani Kabupaten Deli Serdang penerapan sistem kompensasi yang dilakukan masih harus ditinjau kembali. Upah dan gaji yang masih kurang memadai, loyalitas pegawai yang masih kurang yang dapat dilihat dari pelaksanaan tugas yang kurang optimal, sistem pemberian kompensasi dirasakan kurang adil yang dapat dirasakan pegawai yang sudah lama bekerja dengan pegawai baru, juga penghargaan kepada pegawai yang dirasakan masih kurang.

Sebelumnya sudah ada penelitian tentang hubungan kompensasi terhadap kepuasan kerja. Potale \& Uhing, (2015) melakukan penelitian mengenai hubungan kompensasi dan stres kerja terhadap kepuasan kerja pegawai pada PT. Bank Sulut Cabang Utama Manado.

Kepemimpinan juga berpengaruh pada kepuasan kerja pegawai. (Potale \& Uhing, 2015) mendefinisikan kepemimpinan merupakan kemampuan individu dengan menggunakan kekuasaannya melakukan proses mempengaruhi, memotivasi, dan mendukung usaha yang memungkinkan orang lain memberikan kontribusi pada pencapaian tujuan organisasi. (Muhammad Busro, 2017) menyatakan, kepemimpinan memiliki 3 dimensi, yaitu: (1) hubungan antara bawahan dengan pemimpin, (2) struktur tugas dan (3) kekuasaan.

Menurut penelitian awal dengan metode wawancara pada salah satu pegawai, kepemimpinan di Yayasan Generasi Amanah Madani Kabupaten Deli Serdang juga harus mendapatkan perhatian lebih. Hubungan antara sebagian bawahan dan pimpinan ada yang masih kurang baik, struktur tugas masih kurang optimal dimana ada sebagian tugas yang tumpang tindih karena ketidakjelasan tanggung jawab misalnya dalam pembuatan administrasi pembelajaran. Selain itu pada banyak kasus pimpinan kurang bisa mengambil keputusan tegas, misalnya terhadap keterlambatan pegawai, pelanggaran aturan oleh bawahan dan sebagainya yang merupakan indikasi lemahnya kekuasaan pimpinan.

Sebelumnya telah ada penelitian tentang hubungan kepemimpinan terhadap kepuasan kerja. Dolphina, (2012) melakukan penelitian tentang hubungan motivasi, kepemimpinan dan budaya kerja terhadap kepuasan kerja pegawai serta dampaknya pada kinerja perusahaan.

Selanjutnya menurut penelitian awal dengan metode wawancara salah seorang pegawai di Yayasan Generasi Amanah Madani Kabupaten Deli Serdang, fasilitas kerja juga masih belum mencukupi. Menurut (Moenir, 2014), fasilitas kerja adalah segala sesuatu yang digunakan, dipakai, ditempati, oleh pegawai baik dalam hubungan langsung pekerjaan maupun untuk kelancaran pekerjaan. Menurut (Sofyandi, 2016), fasilitas kerja dalam perusahaan terdiri dari (1) mesin dan peralatan, (2) prasarana, (3) perlengkapan kantor, (4) peralatan inventaris, (5) tanah dan bangunan, dan (6) transportasi. 
Kurang memadainya fasilitas kerja sering kali menyebabkan kendala pegawai dalam melaksanakan pekerjaannya. Misalnya jumlah komputer yang kurang, sehingga sering kali tugas-tugas administrasi terkendala. Selain itu ada beberapa prasarana penting yang belum mencukupi, seperti ruangan guru yang sempit dan kurangnya jumlah kamar mandi. Perlengkapan kantor masih belum mencukupi, misalnya meja dan kursi khusus untuk guru, inventaris praktek pembelajaran masih kurang, tanah masih kurang memadai karena lahan parkir yang masih kurang mencukupi, begitu juga transportasi khusus yang tidak tersedia.

Kurang memadainya fasilitas kerja tentu berdampak pada kepuasan kerja pegawai. Seperti teori (Soekarso, Sosro, Putong, \& Hidayat, 2010), salah satu faktor yang mempengaruhi kepuasan kerja adalah faktor fisik, termasuk fasilitas kerja di dalamnya. Sebelumnya telah ada penelitian tentang hubungan fasilitas kerja terhadap kepuasan kerja. Pangarso dkk (2016) melakukan penelitian tentang pengaruh fasilitas kerja terhadap kepuasan kerja pegawai Divisi Sumber Daya Manusia dan Diklat PT. Dirgantara Indonesia.

\section{KAJIAN LITERATUR \\ Kepuasan Kerja}

Setiap pegawai yang bekerja tentu sangat mengharapkan memperoleh kepuasan kerja, begitu juga dengan organisasi. Kepuasan kerja bagi pegawai berarti bahwa pegawai menganggap pekerjaannya sebagai sesuatu yang menyenangkan. Sementara itu, bagi organisasi kepuasan kerja dapat berdampak pada meningkatnya semangat dan produktivitas kerja pegawai dalam pencapaian tujuan organisasi.

Menurut (Wibowo, 2014) Kepuasan kerja didefinisikan sebagai tingkat perasaan senang seseorang sebagai penilaian positif terhadap pekerjaannya dan lingkungan tempat pekerjaannya. Menurut Newstorm dalam (Fattah, 2017), kepuasan kerja diartikan sebagai perasaan atau emosi yang menyenangkan atau tidak menyenangkan pegawai melihat pekerjaan mereka. Dari berbagai defenisi tentang kepuasan kerja dari para ahli tersebut, dapat didefinisikan bahwa kepuasan kerja merupakan perasaan atau emosi yang positif atau negatif pegawai terhadap pekerjaannya yang berkaitan dengan pengalaman dalam pekerjaannya dan harapannya terhadap pengalaman masa depan.

Allen dalam (Bangun, 2018) menyatakan, Mewujudkan kepuasan kerja bertujuan untuk mengoptimalkan pencapaian organisasi. Karena betapapun sempurnanya rencana-rencana organisasi dan pengawasan serta penelitiannya, bila pegawai tidak dapat menjalankan tugasnya dengan minat dan gembira maka suatu organisasi tidak akan dapat mencapai hasil sebanyak yang sebenarnya dapat dicapainya.

Bangun, (2018) menjelaskan bahwa, Kepuasan kerja bermanfaat dan berpengaruh baik pada peningkatan semangat kerja dan produktivitas. Kepuasan kerja yang semakin baik akan meningkatkan semangat kerja pegawai dan produktivitas kerjanya. Demikian sebaliknya, ketidakpuasan kerja akan membuat semangat kerja dan prduktivitas menurun.

Dengan demikian manfaat dari kepuasan kerja ada pada sisi pegawai, yaitu perasaan menyenangkan dalam melakukan pekerjaan yang ditugaskan kepadanya. Sedangkan tujuan kepuasan kerja dapat dilihat dari sisi organisasi, yaitu meningkatnya produktivitas dan kinerja pegawai dalam pencapaian tujuan organisasi.

Faktor-faktor yang mempengaruhi kepuasan kerja dapat dilihat dari hal-hal yang dapat menimbulkan dan mendorong kepuasan kerja tersebut. George dan Jones (dalam (Fattah, 2017) menjelaskan bahwa kepuasan kerja ditentukan oleh faktor-faktor sebagai berikut : 1). Kepribadian, yaitu perasaan, cara berpikir, dan cara berperilaku seseorang, 2). Nilai-nilai, yaitu nilai kerja intrinsik, ekstrinsik dan nilai-nilai etis, 3). Situasi kerja, yaitu pekerjaan itu sendiri, 
rekan kerja, pimpinan dan bawahan, kondisi pekerjaan fisik, jam kerja, kompensasi dan keamanan kerja, dan 4). Pengaruh sosial, yaitu budaya, kelompok kerja dan sebagainya.

Indikator kepuasan kerja sangat dibutuhkan untuk mengukur kepuasan kerja pegawai. Berbagai indikator tersebut yang nantinya akan diukur untuk mengetahui sejauh mana tingkat kepuasan atau ketidakpuasan kerja pegawai terhadap pekerjaannya. Indikator kepuasan kerja diuraikan (Hasibuan, 2018) sebagai berikut : 1). kedisplinan, berarti tingkat di mana pegawai mematuhi semua aturan yang berlaku di dalam organisasi, 2). moral kerja, mencerminkan perilaku pegawai dalam bekerja sehari-hari seperti kejujuran dan sikap saling menghormati, 3). turn over (perputaran pegawai), terjadi saat pegawai keluar dari organisasi tempat ia bekerja.

\section{Kompensasi}

Kompensasi secara umum dapat diartikan sebagai balas jasa yang diberikan organisasi kepada pegawai atas hasil kerja dan kontribusi yang diberikan pegawai kepada organisasi melalui pekerjaan yang dilakukannya. Menurut (Kasmir, 2016), Kompensasi adalah balas jasa yang diberikan kepada pegawai, baik yang bersifat keuangan maupun non keuangan. Tujuan kompensasi menurut (Kasmir, 2016) adalah : memberikan hak pegawai, memberikan rasa keadilan, memperoleh pegawai yang berkualtias, mempertahankan pegawai, menghargai pegawai, pengendalian biaya, memenuhi peraturan pemerintah, dan menghindari konflik. Ada banyak faktor yang menjadi pertimbangan dalam menetapkan kompensasi kepada pegawai dalam suatu organisasi. Berbagai faktor tersebut mempengaruhi jenis dan besarnya kompensasi yang diberikan organisasi kepada pegawai. Menurut (Kasmir, 2016) faktor-faktor yang mempengaruhi kompensasi adalah sebagai berikut : pendidikan, pengalaman, beban pekerjaan dan tanggung jawab, jabatan, jenjang kepangkatan/golongan, prestasi kerja, dan pertimbangan lainnya.

Secara umum ada beberapa indikator kompensasi. Adapun indikator-indikator kompensasi menurut (Rivai \& Sagala, 2011) adalah 1). Upah dan gaji, yaitu cara perusahaan memberikan balas jasa kepada pegawai atas usaha, pengorbanan dan kerja keras yang dilakukan untuk meningkatkan produktivitas perusahaan, 2). Loyalitas, yaitu kesetiaan pegawai terhadap perusahaan sehingga pegawai bekerja dengan semangat dan produktivitas tinggi untuk mencapai target perusahaan, 3). Keadilan, menjaga prinsip keadilan dengan tidak membedakan pegawai satu dengan yang lainnya, 4). Penghargaan, yaitu memperkuat perilaku pegawai, dengan memberikan penghargaan kepada pegawai.

\section{Kepemimpinan}

Kepemimpinan merupakan salah satu fungsi manajemen yang penting dan strategis, karena kepemimpinan dapat menggerakkan, memberdayakan, dan mengarahkan sumber daya secara efektif dan efisien ke arah pencapaian tujuan yang ingin dicapai. Wibowo, (2015) mendefinisikan, Kepemimpinan merupakan kemampuan individu dengan menggunakan kekuasaannya melakukan proses mempengaruhi, memotivasi, dan mendukung usaha yang memungkinkan orang lain memberikan kontribusi pada pencapaian tujuan organisasi.

Kepemimpinan memiliki tujuan dan manfaat pada pemberdayaan sumber daya organisasi yang efektif dan efisien dalam pencapaian organisasi. Menurut (Daulay, Khair, Putri, \& Astuti, 2017) tentang tujuan kepemimpinan, Kepemimpinan yang efektif bertujuan dan memiliki manfaat untuk menyelamatkan organisasi yang dipimpinnya, bahkan menghantarkannya dalam penciptaan kinerja yang andal serta pencapaian sasaran yang gemilang.

Kepemimpinan dipengaruhi oleh banyak faktor. Berbagai faktor tersebut yang mempengaruhi efektivtias kepemimpinan dan berbedanya gaya kepemimpinan yang diterapkan oleh pemimpin. Colquitt, dkk dalam (Wibowo, 2015) menjelaskan bahwa, Ada beberapa faktor 
yang mempengaruhi efektivitas kepemimpinan, yaitu pemilihan gaya pengambilan keputusan secara optimal, bauran perilaku sehari-hari secara optimal, dan bauran perilaku transactional dan transformational secara optimal.

Menurut Busro, (2018) kepemimpinan memiliki 3 dimensi, yaitu : (1) hubungan antara bawahan dengan pemimpin, (2) struktur tugas dan (3) kekuasaan. Masing-masing memiliki indikator sebagai berikut : Indikator hubungan bawahan dan pemimpin, yaitu : (1) kemampuan menghormati hak dan kewajiban pegawai, (2) komunikasi yang hangat antara pimpinan dan pegawai, (3) membantu memecahkan persoalan pegawai, (4) menghargai hasil kerja pegawai, dan (5) bersikap objektif pada bawahan. Indikator struktur tugas, yaitu : (1) kesederhanaan rencana kerja yang dapat disosialisasikan, (2) realisasi rencana kerja, dan (3) kejelasan tanggung jawab terhadap pekerjaan. Indikator kekuasaan, yaitu : (1) kemampuan memerintah bawahan, (2) ketegasan dalam mengambil keputusan, dan (3) mengembangkan kualitas bawahan.

\section{Fasilitas Kerja}

Fasilitas kerja tidak dapat diabaikan dalam melakukan operasional pekerjaan. Fasilitas kerja berperan sangat penting agar operasional organisasi dapat dikerjakan lebih baik, lebih tepat, dan lebih cepat. Moenir, (2014) menyatakan, Fasilitas sebagai segala sesuatu yang digunakan, dipakai, ditempati, oleh pegawai baik dalam hubungan langsung pekerjaan maupun untuk kelancaran pekerjaan.

Fasilitas kerja sangat bermanfaat sekali untuk pelaksanaan operasional perusahaan atau organisasi dalam pencapaian tujuannya. Menurut Djoyowirono dalam (Hasibuan, 2018) Fasilitas kerja dapat mempengaruhi atau meningkatkan efisiensi dan efektivitas kerja. Hal ini menunjukkan ada bahwa fasilitas kerja akan sangat menentukan efektivitas dan efisiensi dalam pencapaian tujuan organisasi. Fasilitas kerja terdiri atas berbagai macam yang berbeda bentuk dan kegunaannya. Moenir, (2014) menjelaskan, Fasilitas dibagi menjadi 3 golongan, yaitu fasilitas alat kerja, fasilitas perlengkapan kerja dan fasilitas sosial.

Dalam menentukan fasilitas yang disediakan oleh organisasi haruslah mempertimbangkan faktor yang dapat menunjang kinerja pegawai. Fasilitas kerja pada setiap perusahaan akan berbeda dalam bentuk dan jenisnya, tergantung pada jenis usaha dan besar kecilnya perusahaan tersebut. Menurut (Sofyandi, 2016) fasilitas kerja dalam perusahaan terdiri dari, 1). Mesin dan peralatan, 2). Prasarana, 3). Perlengkapan kantor, 4). Peralatan inventaris, 5). Tanah dan bangunan, dan 6). Alat transportasi.

\section{METODE PENELITIAN}

Penelitian ini merupakan penelitian asosiatif kausal dengan pendekatan deskriptif kuantitatif. Jenis data yang digunakan pada penelitian ini adalah data primer dan data sekunder. Data primer diperoleh dari hasil pengolahan langsung dari objeknya, sedangkan data sekunder merupakan data yang peneliti peroleh dari buku-buku dan sumber data lainnya. Lokasi penelitian berada di Yayasan Generasi Amanah Madani yang beralamat di Jalan Irian Barat Dusun 17 No. 1 A Desa Sampali, Kecamatan Percut Sei Tuan, Kabupaten Deli Serdang, Sumatera Utara. Dalam penelitian ini, sampel diambil dari seluruh populasi yang ada, yaitu 42 orang pegawai pada Yayasan Generasi Amanah Madani di Kabupaten Deli Serdang. Instrumen pengumpulan data yang digunakan adalah wawancara dan kuesioner. SEdangkan teknik analisis data menggunakan analisis regresi linier berganda. 


\section{HASIL DAN PEMBAHASAN}

\section{Hasil}

Uji normalitas untuk melihat apakah dalam model regresi, variabel dependen dan independennya memiliki distribusi normal atau tidak. Jika data menyebar di sekitar garis diagonal dan mengikuti arah garis diagonal maka model regresi memenuhi asumsi normalitas.

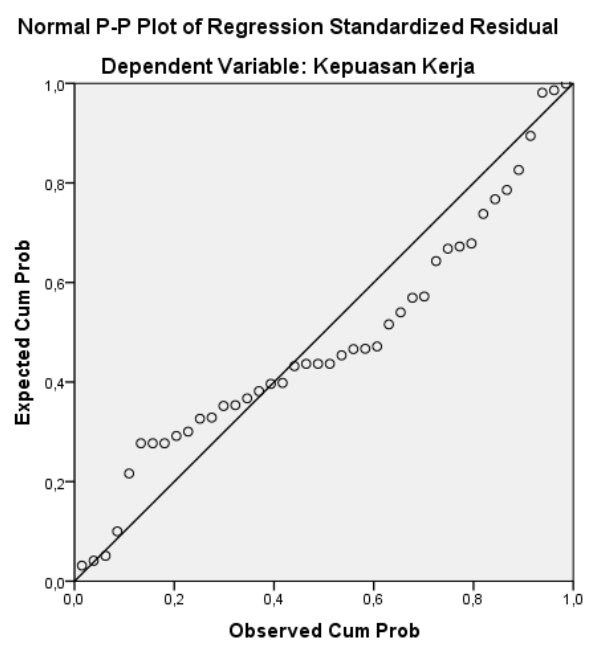

\section{Gambar 1. Hasil Uji Normalitas Menggunakan P-Plot}

Gambar tersebut menunjukkan bahwa titik-titik telah membentuk dan mengikuti arah garis diagonal pada gambar, dengan demikian dapat dinyatakan bahwa data telah terdistribusi secara normal.

Uji Multikoleniaritas bertujuan untuk menguji apakah model regresi ditemukan adanya korelasi yang kuat antara variabel independen dengan melihat nilai VIF (variance inflasi factor) tidak melebihi 4 atau 5. Hines dan Montgomery dalam (Juliandi, Irfan, \& Manurung, 2015).

Tabel 1. Hasil Uji Multikolinieritas

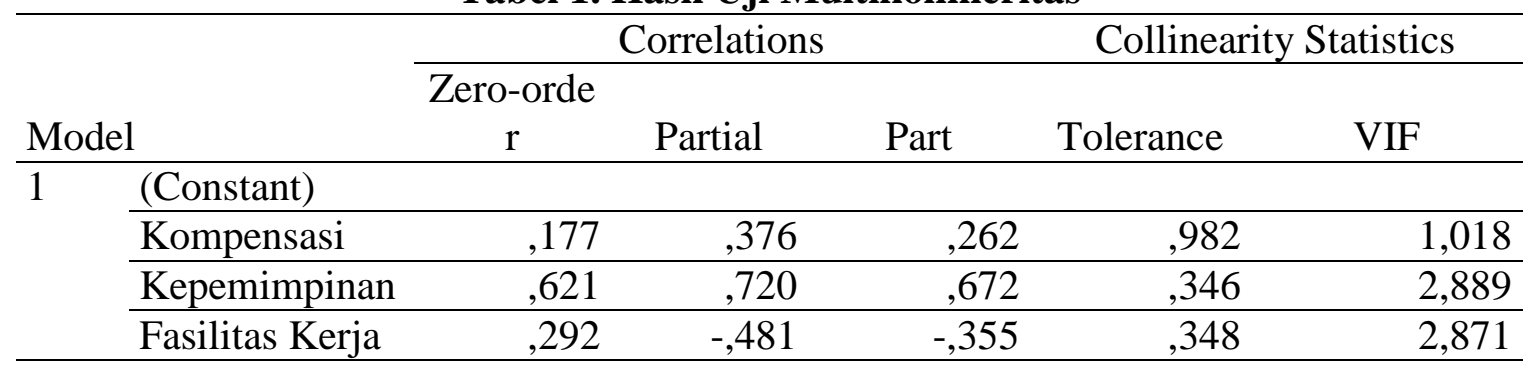

Jika dilihat pada tabel di atas diketahui bahwa variabel kompensasi $\left(\mathrm{X}_{1}\right)$, kepemimpinan $\left(\mathrm{X}_{2}\right)$ dan fasilitas kerja $\left(\mathrm{X}_{3}\right)$ telah terbebas dari multikolinieritas dimana masing-masing nilai VIF tidak melebihi 4 atau 5.

Uji heteroskedastisitas bertujuan untuk menguji apakah dalam model regresi terjadi ketidaknyamanan vaiance dari residual pengamatan satu ke pengamatan yang lain. Jika variance residual dari suatu pengamatan yang lain tetap maka dikatakan homokedastisitas, dan jika variance berbeda dikatakan heteroskedastisitas. Model yang baik adalah tidak terjadi heteroskedastisitas. 


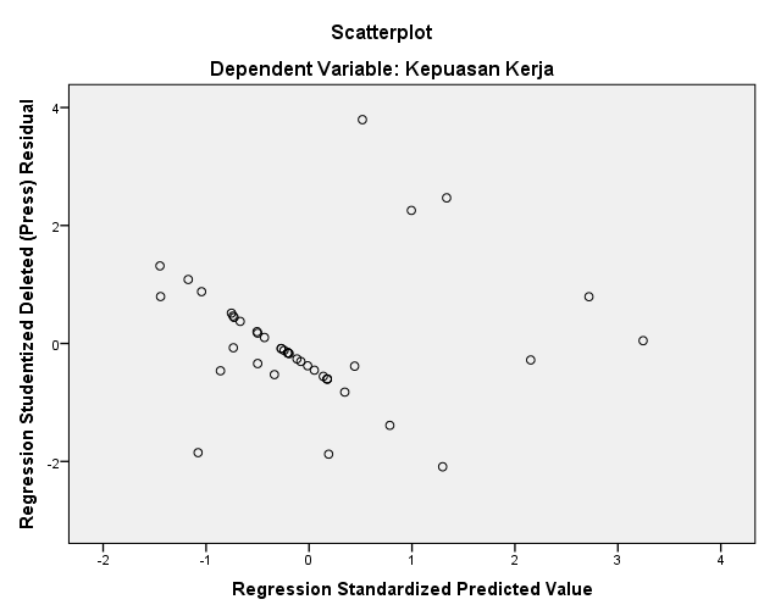

Gambar 2. Hasil Uji Heteroskedastisitas

Uji ini akan menyatakan terbebas dari Heteroskedastisitas jika titik-titik yang terdapat pada gambar tersebar secara acak. Gambar di atas menunjukkan suatu pola yang tidak jelas menyebar baik diatas maupun dibawah angka 0 pada sumbu Y.

\section{Regresi Linier Berganda}

Analisis regresi disusun untuk melihat hubungan yang terbangun antara variabel penelitian, apakah hubungan yang terbangun positif atau hubungan negatif. Berdasarkan olahan data yang telah dilakukan, maka dapat diketahui bahwa model hubungan dari analisis regresi linier berganda dapat dilihat dari tabel berikut ini :

Tabel 2. Coefficients Regresi Linier Berganda

\begin{tabular}{llrrr}
\hline & & \multicolumn{2}{c}{$\begin{array}{c}\text { Unstandardized } \\
\text { Coefficients }\end{array}$} & \multicolumn{2}{c}{$\begin{array}{c}\text { Standardized } \\
\text { Coefficients }\end{array}$} \\
\cline { 2 - 5 } Model & \multicolumn{1}{c}{ B } & Std. Error & \multicolumn{1}{c}{ Beta } \\
\hline 1 & (Constant) & 3,181 & 5,246 & \\
\cline { 2 - 5 } & Kompensasi &, 084 &, 034 &, 265 \\
\cline { 2 - 5 } & Kepemimpinan &, 566 &, 088 & 1,142 \\
\cline { 2 - 5 } & Fasilitas Kerja &, 754 &, 223 &, 602 \\
\hline
\end{tabular}

Berdasarkan pada tabel di atas dapat disusun model penelitian persamaan regresinya adalah sebagai berikut: $\mathbf{Y}=\mathbf{3 , 1 8 1}+\mathbf{0 , 0 8 4 X _ { 1 }}+\mathbf{0 , 5 6 6} \mathbf{X}_{\mathbf{2}}+\mathbf{0 , 7 5 4 X _ { 3 }}$.

Model persamaan regresi berganda tersebut bermakna bahwa Nilai Konstanta sebesar 3,181 yang berarti bahwa jika variabel independen yaitu kompensasi $\left(\mathrm{X}_{1}\right)$, kepemimpinan $\left(\mathrm{X}_{2}\right)$ dan fasilitas kerja $\left(\mathrm{X}_{3}\right)$ sama dengan nol, maka kepuasan kerja $(\mathrm{Y})$ adalah sebesar 3,181. Maka pada persamaan di atas, $Y=3,181$. Nilai koefisien regresi $X_{1}=0,084$ menunjukkan apabila kompensasi mengalami kenaikan sebesar $100 \%$ maka akan meningkatkan kepuasan kerja pegawai pada Yayasan Generasi Amanah Madani Kabupaten Deli Serdang Sumatera Utara sebesar $8,4 \%$, dengan catatan variabel yang lain tetap. Nilai koefisien regresi $\mathrm{X}_{2}=0,566$ menunjukkan apabila kepemimpinan mengalami kenaikan sebesar $100 \%$ maka akan mengakibatkan meningkatnya kepuasan kerja pegawai pada Yayasan Generasi Amanah Madani Kabupaten Deli Serdang Sumatera Utara sebesar 56,6\%. Nilai koefisien regresi $\mathrm{X}_{3}=$ 0,754 menunjukkan apabila fasilitas kerja mengalami kenaikan sebesar 100\% maka akan 
mengakibatkan meningkatnya kepuasan kerja pegawai pada Yayasan Generasi Amanah Madani Kabupaten Deli Serdang Sumatera Utara sebesar 75,4\%.

\section{Pengujian Hipotesis}

\section{Uji Parsial (Uji t)}

Uji statistik t dilakukan untuk menguji apakah variabel bebas (X) secara individual mempunyai pengaruh yang signifikan atau tidak terhadap variabel terikat (Y).

Tabel 3. Hasil Uji t

\begin{tabular}{|c|c|c|c|c|c|c|}
\hline \multirow{2}{*}{\multicolumn{2}{|c|}{ Model }} & \multicolumn{2}{|c|}{$\begin{array}{c}\text { Unstandardized } \\
\text { Coefficients }\end{array}$} & \multirow{2}{*}{$\begin{array}{c}\text { Standardized } \\
\text { Coefficients } \\
\text { Beta }\end{array}$} & \multirow[b]{2}{*}{$\mathrm{t}$} & \multirow[b]{2}{*}{ Sig. } \\
\hline & & $\mathrm{B}$ & Std. Error & & & \\
\hline \multirow[t]{4}{*}{1} & (Constant) & 3,181 & 5,246 & & 606 &, 548 \\
\hline & Kompensasi & ,084 & ,034 & ,265 & 2,499 & ,017 \\
\hline & Kepemimpinan & ,566 & ,088 & 1,142 & 6,400 &, 000 \\
\hline & Fasilitas Kerja &, 754 & 223 & ,602 & 3,382 &, 002 \\
\hline
\end{tabular}

Variabel $\mathrm{X}_{1}$ yaitu kompensasi memiliki signifikansi sebesar 0,017 atau lebih kecil dari 0,05, artinya bahwa kompensasi berpengaruh signifikan terhadap kepuasan kerja pegawai. Pengaruh kompensasi $\left(\mathrm{X}_{1}\right)$ terhadap kepuasan kerja $(Y)$ diperoleh nilai $t_{\text {hitung }} 2.499>t_{\text {tabel }} 1.685$ dengan probabilitas Sig 0,017, lebih kecil dari $\alpha=0,05$. Dapat di simpulkan bahwa kompensasi $\left(\mathrm{X}_{1}\right)$ secara parsial mempunyai pengaruh positif signifikan terhadap kepuasan kerja $(\mathrm{Y})$.

Variabel $\mathrm{X}_{2}$ yaitu kepemimpinan memiliki signifikan sebesar 0,000 atau lebih kecil dari 0,05 , artinya bahwa kepemimpinan berpengaruh signifikan terhadap kepuasan kerja pegawai. Pengaruh kepemimpinan $\left(\mathrm{X}_{2}\right)$ terhadap kepuasan kerja $(\mathrm{Y})$ diperoleh nilai $\mathrm{t}_{\text {hitung }} 6.400>\mathrm{t}_{\text {tabel }}$ 1.685 dengan probabilitas Sig 0,000, lebih kecil dari $\alpha=0,05$. Dapat di simpulkan bahwa kepemimpinan $\left(\mathrm{X}_{2}\right)$ secara parsial berpengaruh positif signifikan terhadap kepuasan kerja $(\mathrm{Y})$.

Variabel $\mathrm{X}_{3}$ yaitu fasilitas kerja memiliki signifikan sebesar 0,002 atau lebih kecil dari 0,05 , artinya bahwa fasilitas kerja berpengaruh signifikan terhadap kepuasan kerja pegawai. Pengaruh fasilitas kerja $\left(\mathrm{X}_{3}\right)$ terhadap kepuasan kerja $(\mathrm{Y})$ diperoleh nilai $\mathrm{t}_{\text {hitung }} 3.382>\mathrm{t}_{\text {tabel }}$ 1.685 dengan probabilitas Sig 0,002, lebih kecil dari $\alpha=0,05$. Dapat di simpulkan bahwa fasilitas kerja $\left(\mathrm{X}_{3}\right)$ secara parsial mempunyai pengaruh positif signifikan terhadap kepuasan kerja (Y).

\section{Uji Simultan (Uji F)}

Uji statistik F (simultan) dilakukan untuk mengetahui apakah variabel bebas (independent) secara bersama-sama berpengaruh secara signifikan atau tidak terhadap variabel terikat (dependen).

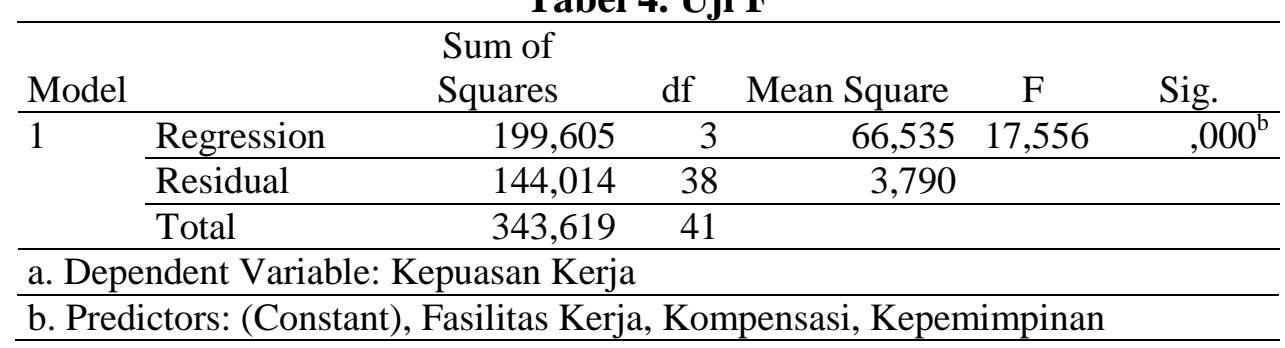

Berdasarkan dari tabel uji F diketahui bahwa terdapat nilai signifikan sebesar 0,000, nilai signifikan ini lebih kecil dari 0,05 artinya bahwa kompensasi, kepemimpinan dan fasilitas kerja 
berpengaruh signifikan terhadap kepuasan kerja pegawai. Jika dibandingkan nilai $\mathrm{F}_{\text {hitung }}$ dengan $F_{\text {tabel }}$ maka dihasilkan $17.556>2.85$ sehingga disimpulkan bahwa kompensasi, kepemimpinan dan fasilitas kerja secara bersama-sama berpengaruh signifikaan terhadap kepuasan kerja pegawai.

\section{Koefisien Determinasi}

Uji determinasi ini untuk melihat seberapa besar kompensasi, kepemimpinan dan fasilitas kerja dalam menjelaskan variasi variabel dependen yaitu kepuasan kerja. Untuk mengetahui besarnya determinasi kompensasi, kepemimpinan dan fasilitas kerja dalam menjelaskan variasi variabel dependennya yaitu kepuasan kerja dapat dilihat pada tabel berikut ini :

Tabel 5. Koefisien Determinasi (R-Square)

\begin{tabular}{lcccc}
\hline Model & R & R Square & $\begin{array}{c}\text { Adjusted R } \\
\text { Square }\end{array}$ & $\begin{array}{c}\text { Std. Error of the } \\
\text { Estimate }\end{array}$ \\
\hline 1 &, $762^{\mathrm{a}}$ &, 581 &, 548 & 1,94675 \\
\hline \multicolumn{4}{l}{ a. Predictors: (Constant), Fasilitas Kerja, Kompensasi, Kepemimpinan } \\
\hline \multicolumn{2}{l}{ b. Dependent Variable: Kepuasan Kerja } \\
\hline
\end{tabular}

Berdasarkan pada tabel di atas diketahui bahwa nilai $\mathrm{R}_{\text {square }}$ adalah sebesar 0,581. Sementara itu, Koefisien Determinasi (KD) dirumuskan sebagai berikut : KD $=\mathrm{R}^{2} \mathrm{x} 100 \%$.

Maka nilai $\mathrm{KD}=0,581 \times 100 \%=58,1 \%$. Artinya bahwa kompensasi, kepemimpinan dan fasilitas kerja mampu untuk menjelaskan kepuasan kerja pegawai pada Yayasan Generasi Amanah Madani Kabupaten Deli Serdang Sumatera Utara adalah sebesar 58,1\% dan sisanya $41,9 \%$ dijelaskan oleh variabel bebas yang lainnya yang tidak diikutsertakan ke dalam model penelitian ini.

\section{PEMBAHASAN}

\section{Pengaruh Kompensasi terhadap Kepuasan Kerja}

Berdasarkan hasil penelitian, diketahui bahwa kompensasi berpengaruh signifikan secara parsial terhadap kepuasan kerja pegawai pada Yayasan Generasi Amanah Madani Kabupaten Deli Serdang Sumatera Utara. Hal ini berarti berarti bawa kompensasi yang diberikan akan mampu meningkatkan kepuasan kerja pegawai.

Hasil analisis juga menunjukkan bahwa berkaitan dengan kompensasi, kepuasan kerja pegawai dapat menurun karena berbagai aspek sebagai berikut : 1). Jumlah upah dan gaji yang diterima sesuai dengan pekerjaan, 2). Kepatuhan dan ketaatan pegawai pada aturan yang ditetapkan oleh yayasan, 3). Pencapaian target pegawai pada pekerjaan yang diberikan, 4). sistem kompensasi atau penggajian adil sesuai pendidikan, 5). Sistem kompensasi atau penggajian adil sesuai masa kerja, 6). Sistem kompensasi atau penggajian adil sesuai beban kerja dan tanggung jawab, 7). Sistem kompensasi atau penggajian adil sesuai prestasi kerja. Hasil penelitian ini menyatakan bahwa ada pengaruh positif dan signifikan antara kompensasi terhadap kinerja pegawai. Hasil penelitian sejalan dengan dengan hasil penelitian terdahulu yang dilakukan oleh (Azhar, Nurdin, \& Siswadi, 2020); (Nasution, Prayogi, Jufrizen, Pulungan, \& Juliandi, 2019); (Jufrizen, Lumbanraja, Salim, \& Gultom, 2017); (Handoko \& Rambe, 2018); (Tamali \& Munasip, 2019); (Jufrizen, 2015); (Jufrizen, 2016); (Andriany, 2019); (Mahendrawan \& Indrawati, 2015); dan (Bancin, 2016) yang menunjukan bahwa kompensasi berpengaruh signifikan terhadap kinerja pegawai. 


\section{Pengaruh Kepemimpinan terhadap Kepuasan Kerja}

Berdasarkan hasil penelitian, diketahui bahwa kepemimpinan berpengaruh signifikan secara parsial terhadap kepuasan kerja pegawai pada Yayasan Generasi Amanah Madani Kabupaten Deli Serdang Sumatera Utara. Hal ini berarti berarti bahwa kepemimpinan yang baik akan mampu meningkatkan kepuasan kerja pegawai.

Hasil analisis juga menunjukkan bahwa berkaitan dengan kepemimpinan, kepuasan kerja pegawai dapat menurun karena berbagai aspek sebagai berikut : 1). Pimpinan selalu memberi solusi dalam setiap pekerjaan pegawai, 2). Pimpinan menghargai hasil kerja pegawai dengan memberikan kesempatan promosi sesuai hasil kerja, 3). Kemampuan pegawai melaksanakan pekerjaan sesuai rencana kerja yang ditetapkan pimpinan, 4). Kontrol pimpinan terhadap pekerjaan pegawai, 5). Pimpinan membagi tugas dengan jelas sesuai tanggung jawab masing-masing. Hasil penelitian ini menyatakan bahwa ada pengaruh positif dan signifikan antara kepemimpinan terhadap kinerja pegawai. Hasil penelitian ini sejalan dengan hasil penelitian terdahulu yang dilakukan oleh (Jufrizen, 2017); (Brahmasari \& Suprayetno, 2008); (Mujiatun, Jufrizen, \& Ritonga, 2019); (Astuti \& Iverizkinawati, 2018); (Muis, Nasution, Azhar, \& Radiman, 2018); (Hidayati \& Saputra, 2018); (Kusmaningtyas, 2013); (Bahri, 2018); (Siahaan, Salim, \& Siahaan, 2014) yang menunjukan bahwa kepemimpinan berpengaruh signifikan terhadap kinerja pegawai.

\section{Pengaruh Fasilitas Kerja terhadap Kepuasan Kerja}

Berdasarkan hasil penelitian, diketahui bahwa fasilitas kerja berpengaruh signifikan secara parsial terhadap kepuasan kerja pegawai pada Yayasan Generasi Amanah Madani Kabupaten Deli Serdang Sumatera Utara. Hal ini berarti berarti bahwa fasilitas yang lengkap akan mampu meningkatkan kepuasan kerja pegawai.

Hasil analisis juga menunjukkan bahwa berkaitan dengan kepemimpinan, kepuasan kerja pegawai dapat menurun karena aspek ketersediaan perlengkapan kantor untuk komunikasi. Hasil penelitian ini menyatakan bahwa ada pengaruh positif dan signifikan antara fasilitas terhadap kinerja pegawai. Hasil penelitian ini sejalan dengan hasil penelitian terdahulu yang dilakukan oleh (Dahlius \& Ibrahim, 2016); (Pangarso, Firdaus, \& Moeliono, 2016); (Asri, Ansar, \& Munir, 2019); (Anam \& Rahardja, 2017) yang menunjukan bahwa fasilitas kerja berpengaruh signifikan terhadap kinerja pegawai.

\section{Pengaruh Kompensasi, Kepemimpinan dan Fasilitas Kerja terhadap Kepuasan Kerja}

Berdasarkan hasil penelitian mengenai pengaruh antara kompensasi, kepemimpinan dan fasilitas kerja terhadap kepuasan kerja pegawai pada Yayasan Generasi Amanah Madani Kabupaten Deli Serdang Sumatera Utara pada penelitian ini sudah jelas terbukti ada pengaruh secara simultan, di mana hasil uji $\mathrm{F}$ di dapat nilai $\mathrm{F}_{\text {hitung }} \geq \mathrm{F}_{\text {tabel }}$ yaitu $9.555 \geq 2.85$ dengan signifikan $0,000<0,05$. Karena $F_{\text {hitung }}$ lebih besar dari $F_{\text {tabel }}$ maka $\mathrm{H} 0$ di tolak dan Ha di terima artinya ada pengaruh antara kompensasi, kepemimpinan dan fasilitas kerja terhadap kepuasan kerja pegawai pada Yayasan Generasi Amanah Madani Kabupaten Deli Serdang Sumatera Utara. Hasil penelitian ini menyatakan bahwa ada pengaruh antara kompensasi, kepemimpinan dan fasilitas kerja terhadap kepuasan kerja.

\section{PENUTUP}

Simpulan dari penelitian ini adalah: 1). Kompensasi, kepemimpinan dan fasilitas kerja secara parsial berpengaruh signifikan terhadap kepuasan kerja, 2). Kompensasi, kepemimpinan dan fasilitas kerja secara simultan berpengaruh signifikan terhadap kepuasan kerja. Saran dan rekomendasi yang dapat kepada Yayasan Generasi Amanah Madani Kabupaten Deli Serdang, 
Sumatera Utara dalam peningkatan kepuasan kerja pegawai adalah sebagai berikut : a). Berkaitan dengan kompensasi, untuk lebih memperhatikan : jumlah upah dan gaji yang diterima sesuai dengan pekerjaan, kepatuhan dan ketaatan pegawai pada aturan yang ditetapkan oleh yayasan, pencapaian target pegawai pada pekerjaan yang diberikan, sistem kompensasi atau penggajian adil sesuai pendidikan, sistem kompensasi atau penggajian adil sesuai masa kerja, sistem kompensasi atau penggajian adil sesuai beban kerja dan tanggung jawab, sistem kompensasi atau penggajian adil sesuai prestasi kerja, b). Berkaitan dengan kepemimpinan, untuk lebih memperhatikan hal berikut : pimpinan selalu memberi solusi dalam setiap pekerjaan pegawai, pimpinan menghargai hasil kerja pegawai dengan memberikan kesempatan promosi sesuai hasil kerja, kemampuan pegawai melaksanakan pekerjaan sesuai rencana kerja yang ditetapkan pimpinan, kontrol pimpinan terhadap pekerjaan pegawai, pimpinan membagi tugas dengan jelas sesuai tanggung jawab masing-masing, c). Berkaitan dengan fasilitas kerja, untuk lebih memperhatikan ketersediaan perlengkapan kantor untuk komunikasi.

\section{REFERENSI}

Anam, K., \& Rahardja, E. (2017). Pengaruh Fasilitas Kerja, Lingkungan Kerja Dan Fisik dan Kepuasan kerja Terhadap Kinerja Karyawan. Diponegoro Journal of Management, 6(4), $1-11$.

Andriany, D. (2019). Pengaruh Kompensasi dan Lingkungan Kerja Terhadap Kepuasan Kerja Karyawan Pada PT. Repex Perdana Internasional (License of Federal Express) Medan. Proseding Seminar Nasional Kewirausahaan, 1, 392-398. https://doi.org/htpps://doi.org/10.30596/snk.v1i1.3642

Asri, A., Ansar, A., \& Munir, A. R. (2019). Pengaruh Kompensasi, Fasilitas Kerja, Dan Kepemimpinan Terhadap Kinerja Melalui Kepuasan Kerja Pegawai Pada Rektorat Uin Alauddin Makassar. Journal of Management, 2(1).

Astuti, R., \& Iverizkinawati, I. (2018). Pengaruh Kepemimpinan dan Lingkungan Kerja Terhadap Kepuasan Kerja Karyawan Pada PT. Sarana Agro Nusantara Medan. Jurnal Ilman, 6(1), 26-41.

Azhar, M. E., Nurdin, D. U., \& Siswadi, Y. (2020). Pengaruh Disiplin Kerja dan Kompensasi Terhadap Kepuasan Kerja Karyawan. Jurnal Humaniora: Jurnal Ilmu Sosial, Ekonomi Dan Hukum, 4(1), 46-60. https://doi.org/10.30601/humaniora.v4i1.422

Bahri, M. S. (2018). Pengaruh Kepemimpinan, Lingkungan Kerja, Budaya Organisasi dan Motivasi Terhadap Kepuasan Kerja yang Berimplikasi Terhadap Kinerja Dosen. Surabaya: Jakad Publishing.

Bancin, A. (2016). Pengaruh Kompensasi Non Finansial Dan Pengembangan Karir Terhadap Kepuasan Kerja Karyawan Pada PT. Jasa Marga (PERSERO) Cabang Belmera Medan. Jurnal Ilmiah Manajemen Bisnis, 17(2), 27-40.

Bangun, W. (2018). Manajemen Sumber Daya Manusia. Jakarta: Erlangga.

Brahmasari, I. A., \& Suprayetno, A. (2008). Pengaruh Motivasi Kerja, Kepemimpinan dan Budaya Organisasi Terhadap Kepuasan Kerja Karyawan serta Dampaknya pada Kinerja Perusahaan (Studi kasus pada PT. Pei Hai International Wiratama Indonesia). Jurnal Manajemen Dan Kewirausahaan, 10(2), 124-135. https://doi.org/10.9744/jmk.10.2.pp.\%20124-135

Busro, M. (2018). Teori Teori Manajemen Sumber Daya Manusia. Jakarta: Kencana.

Busro, M. (2017). Manajemen Sumber Daya Manusia. (Expest, Ed.). Yogyakarta.

Dahlius, A., \& Ibrahim, M. (2016). Pengaruh Fasilitas Kerja Terhadap Kepuasan Kerja Karyawan Pada PT. Bank Riau Kepri Cabang Teluk Kuantan Kabupaten Kuantan 
Singingi. Jom Fisip, 3(2), 1-11.

Daulay, R., Khair, H., Putri, L. P., \& Astuti, R. (2017). Manajemen. Medan: Lembaga penelitian dan Penulisan Ilmiah AQLI.

Dolphina, E. (2012). Pengaruh Motivasi, Kepemimpinan dan Budaya Kerja terhadap Kepuasan Kerja Karyawan serta Dampaknya pada Kinerja Perusahaan. Semantik, 2(1), 1-7.

Fattah, H. (2017). Kepuasan Kerja dan Kinerja Pegawai. Yogyakarta: Elmatera.

Handoko, D. S., \& Rambe, M. F. (2018). Pengaruh Pengembangan Karir dan Kompensasi terhadap Komitmen Organisasi Melalui Kepuasan Kerja. Maneggio: Jurnal Ilmiah Magister Manajemen, 1(1), 31-45. https://doi.org/10.30596/maneggio.v1i1.2238

Hasibuan, M. S. P. (2018). Manajemen Sumber Daya Manusia. (Lia Malyani, Ed.). Bandung: Yrama Widya.

Hidayati, S. N., \& Saputra, S. D. (2018). Pengaruh Kepemimpinan, Kompensasi, Komunikasi, dan Motivasi Kerja terhadap Turnover Intention Pegawai dengan Kepuasan Kerja sebagai "Variabel Antara." Jurnal Maksipreneur, 7(2), 162-1173. https://doi.org/10.30588/jmp.v7i2.365

Jufrizen, J. (2015). Pengaruh Kompensasi Dan Pengembangan Karir Terhadap Komitmen Organisasi Dengan Kepuasan Kerja Sebagai Variabel Intervening Pada PT. Perkebunan Nusantara III (Persero) Medan. Jurnal Ilmiah Manejemen Dan Bisnis, 15(1), 37-47. https://doi.org/10.30596/jimb.v15i1.965

Jufrizen, J. (2016). Efek Mediasi Kepuasan Kerja Pada Pengaruh Kompensasi Terhadap Kinerja Karyawan. Jurnal Ilmiah Manajemen Dan Bisnis, 17(1). https://doi.org/10.30596/jimb.v17i1.1209

Jufrizen, J. (2017). Pengaruh Kepemimpinan dan Budaya Organisasi Terhadap Kinerja dengan Kepuasan Kerja sebagai Variabel Intervening. Jurnal Ilmiah Kohesi, 1(1), 166-177.

Jufrizen, J., Lumbanraja, P., Salim, S. R. A., \& Gultom, P. (2017). The Effect of Compensation, Organizational Culture and Islamic Work Ethic Towards the Job Satisfaction and the Impact on the Permanent Lecturers. International Business Management, 11(1), 53-60.

Juliandi, A., Irfan, I., \& Manurung, S. (2015). Metode Penelitian Bisnis : Konsep \& Aplikasi. In F. Zulkarnain (Ed.). Medan : UMSU PRESS.

Kasmir, K. (2016). Manajemen Sumber Daya Manusia. Jakarta: PT Rajagrafindo Persada.

Kusmaningtyas, A. (2013). Pengaruh Iklim Organisasi dan Kepemimpinan Terhadap Kepuasan Kerja Karyawan PT. Persada Jaya Indonesia di Kabupaten Sidoarjo. Jurnal Mitra Ekonomi Dan Manajemen Bisnis, 4(1), 107-120.

Mahendrawan, I. G., \& Indrawati, A. D. (2015). Pengaruh Beban Kerja Dan Kompensasi Terhadap Kepuasan Kerja PT Panca Dewata Denpasar. E-Jurnal Manajemen Unud, 4(11), 3936-3961.

Moenir. (2014). Manajemen Pelayanan Umum Di Indonesia. Jakarta: Bumi Aksara.

Muis, M. R., Nasution, M. I., Azhar, M. E., \& Radiman, R. (2018). Pengaruh kepemimpinan dan self efficacy terhadap kelelahan emosional serta dampaknya terhadap kepuasan kerja dosen. Jurnal Riset Sains Manajemen, 2(3), 131-142. https://doi.org/10.5281/zenodo.1477532

Mujiatun, S., Jufrizen, J., \& Ritonga, P. (2019). Model Kelelahan Emosional: Antaseden Dan Dampaknya Terhadap Kepuasan Kerja Dan Komitmen Organisasi Dosen. MIX: Jurnal Ilmiah Manajemen, 9(3), 447-465. https://doi.org/10.22441/mix.2019.v9i3.005

Nasution, M. I., Prayogi, M. A., Jufrizen, J., Pulungan, D. R., \& Juliandi, A. (2019). Compensation and Organizational Commitment: The Mediating Role of Job Satisfaction. In Proceedings of The 2nd International Conference on Advance And Scientific Innovation, ICASI 2019 (pp. 1-10). 
Pangarso, A., Firdaus, F. F., \& Moeliono, N. K. (2016). Pengaruh Fasilitas Kerja Terhadap Kepuasan Kerja Karyawan Divisi Sumber Daya Manusia dan Diklat PT. Dirgantara Indonesia. Jurnal Administrasi Dan Bisnis, 12(1), 50-62.

Potale, R., \& Uhing, Y. (2015). Pengaruh Kompensasi dan Stres Kerja terhadap Kepuasan Kerja Karyawan pada PT. Bank Sulut Cabang Utama Manado. Jurnal EMBA: Jurnal Riset Ekonomi, Manajemen, Bisnis Dan Akuntansi, 3(1), 63-73. https://doi.org/10.35794/emba.v3i1.6567

Rivai, V., \& Sagala, E. J. (2011). Manajemen Sumber Daya Manusia untuk Perusahaan dari Teori ke Praktik. Jakarta: PT Raja Grafindo Persada.

Siahaan, B. N., Salim, S. R. A., \& Siahaan, E. (2014). Pengaruh Kepemimpinan dan Motivasi Kerja Terhadap Kinerja Karyawan Melalui Kepuasan Kerja Karyawan Akademi Manajemen Informatika komputer Medan Business Polytechnic Medan (AMIK MBP) Medan. Jurnal Manajemen Sains, 2(4), 437-481.

Soekarso, Sosro, A., Putong, I., \& Hidayat, C. (2010). Teori Kepemimpinan. Jakarta: Mitra Wacana Media.

Sofyandi, H. (2016). Manajemen Sumber Daya Manusia. Yogyakarta: Graha Ilmu.

Sudaryo, Y., Aribowo, A., \& Sofiati, N. A. (2018). Manajemen Sumber Daya Manusia, Kompensasi Tidak Langsung dan Lingkungan Kerja Fisik. Yogyakarta: ANDI.

Tamali, H., \& Munasip, A. (2019). Pengaruh Kompensasi, Kepemimpinan, Dan Lingkungan Kerja Terhadap Kepuasan Kerja Karyawan. Maneggio: Jurnal Ilmiah Magister Manajemen, 2(1), 55-68. https://doi.org/10.30596/maneggio.v2i1.3403

Wibowo. (2015). Perilaku Dalam Organisasi. Jakarta: Rajawali Pers.

Wibowo, W. (2014). Perilaku Dalam Organisasi. Jakarta: Rajawali Pres. 